\title{
What Comes First, Denuclearization or Peace? Using Willy Brandt's Ostpolitik as a Case for an Integrative Engagement Approach on the Korean Peninsula
}

\author{
Andrew S. Millard \\ Busan University of Foreign Studies, Busan, South Korea
}

\begin{abstract}
The Korean peninsula is witnessing historic events and a dramatic improvement in relations between the two Koreas and their allies. However, there must be caution not only over the true intentions of all actors involved, but also the approach taken to the renewed relations must be carefully considered. In the past engagement policies have been tried and failed, whilst the US has committed itself firmly to a pre-condition that the DPRK foregoes its nuclear weapons program and denuclearizes. This paper argues that the US policy is flawed in that the demand of CVID does not create any spillovers for future relations to be bound by, as shown by the 1994 Agreed Framework. As such, an engagement policy should be employed that follows characteristics of West Germany's Ostpolitik in the 1970s and Kim Daejung's Sunshine Policy.
\end{abstract}

Keywords: denuclearization, engagement, spillovers, linkages, cooperation

\section{Introduction}

Everyone knows the philosophical question "what came first, the chicken or the egg?" Everyone also knows that there is no answer to this question. However, in international relations a similar conundrum often arises between states: Namely how do states approach the dilemma of improving relations by demilitarizing in a hostile environment? This paper focuses that exact question on the current situation on the Korean peninsula, wherein certain groups advocate an engagement policy that could lead to improved relations and in time demilitarization, whilst others demand the complete denuclearization of North Korea as the starting point of negotiations.

The situation on the Korean Peninsula is rather unique. Since the collapse of the Soviet Union the two Koreas have followed polar-opposite foreign policy trajectories. Whilst the South has furthered its domestic democratization, as well as its global economic and political development, emerging as a key regional power in Northeast Asia, the North has travelled on a rollercoaster of rapidly changing foreign policy decisions, seeing it participate in positive Talks and Summits, then quickly resorting to aggressive and isolationist policies. Despite the past experiences, however, the current climate is witnessing a period of unequalled détente, with inter-Korean summits and a US-North Korea summit having taken place.

Yet the summit that took place between the US and North Korea in Singapore on June 12, 2018, was not

\footnotetext{
Andrew S. Millard, Ph.D., Assistant Professor, Department of Paideia, Busan University of Foreign Studies, Busan, South Korea.
} 
straight forward, having also endured a bumpy journey to get there. The sudden cancellation of the summit by President Trump in late May was due to various reasons, although one reason that stood above all others was the policies of the parties regarding denuclearization of the Korean peninsula - the US following its policy of CVID and the North following its policy of maintaining a nuclear deterrent.

This paper will look at the two different approaches to the Korean problem and analyze whether an approach of engagement that develops trust and, through spillovers, leads to peace and eventual denuclearization is more productive, or whether an aggressive unilateral stance demanding full denuclearization from the start is preferable. This paper concerns itself primarily with the idea of using spillovers, and hence the first section will define what spillovers are and also how spillovers can be separated into positive and negative spillovers. The following section will take a closer look at how engagement can produce positive spillovers, namely by studying the rapprochement policy of Willy Brandt in the early 1970s and the more recent Sunshine Policy in Korea in the 1990s and early 2000s. The next section will analyze the US policy of CVID and its likelihood of producing either no spillovers or negative spillovers, using examples of failed attempts at denuclearization, such as the 1994 Agreed Framework.

This paper aims to expand the discourse on the question of denuclearization by utilizing the current situation on the Korean peninsula to advocate a diplomatic approach of integrative engagement, rather than unilateral force. The literature to date focuses mainly on whether denuclearization should happen or not, and fails to analyze how denuclearization should be brought about. By analyzing examples such as Ostpolitik this paper will show that engagement can foster relations leading to peaceful co-existence and cooperation, even if denuclearization is not achieved.

\section{Theoretical Approach}

This study follows the theoretical approach of spillovers, as introduced by Ernst Haas in his re-inventing of functionalism in the 1950s. In order to fully understand why spillovers can be applied to this case, a short analysis of functionalism should also be included. Daddow (2013, pp. 93, 94) discusses the general idea of David Mitrany's post-WWI functionalist theory, stating,

Mitrany argued (1933) state authority in the modern era had been called into question as people began to find solutions to shared security, economic and political concerns across state borders, rather than working within the confines of those borders. Such efforts would increase as individuals saw the benefits of collective endeavours and this interdependence would then lead to peace and further integration across state borders through what has become known as the "spillover" effect of integration.

The main idea behind functionalism, as summarized by Mattli (1999, p. 22), is that "political divisions are a source of conflict among nations. These divisions can be transcended only gradually by seeking out areas of mutuality and establishing a 'working' web of international functional institutions". Mattli further adds, "Areas of functional cooperation are likely to be found in 'low-politics' areas of economic and social life" (ibid.). Mitrany's focus on initial cooperation in "low-politics" areas is also noted by Börzel (2013, p. 504). Heywood (2007, p. 152) defines functionalism as, "incremental steps towards regional integration, within specific areas of policy-making". Based on these ideas, functionalism taken as a whole is far too broad for individual agreements, but the definitions do draw us close to the idea of starting with small areas of cooperation that can be used to build relations. Further, the future integration of the two Koreas into some form of federal or confederal system could also be applied at a later date, and in the mean time the "specific area of policy-making" 
could be applied to economic policy, developing political relations, and also the thornier issue of denuclearization.

The idea that the specific policy areas are varied and plural leads us into Haas' neofunctionalist theory, which Heywood (ibid.) defines as, "a revision of functionalism that recognizes that regional integration in one area generates pressures for further integration in the form of spillover". Chari and Kritzinger (2006, p. 39) also note that neo-functionalism "argues that nation states are forced to enter into relationships with others in order to gain economic benefits, which are presumably no longer confined within state borders. This leads to the development of supranational institutions". Again, we will temporarily ignore the idea that this concept is specific to regional integration and assume that the theory can be applied to relations between two states on more specific areas, especially since in this case the DPRK is being forced to enter into relationships with others for economic benefit. As such, this paper cannot specifically follow the general theory of neo-functionalism, since it is not concerned with the creating of any new supranational institutions; however, it can adopt certain features, namely the characteristic of spillovers.

This paper advocates that positive engagement can only be the result of a process that develops spillovers, or as Greenstein and Polsby (1975, p. 384) call them "functional linkages of issues". Börzel (2013, p. 504) adds, "the functional linkage between issue areas was to create further incentives for the gradual expansion of tasks (Mitrany 1943)". According to Sonny (2015, p. 1), a spillover is "an unexpected consequence of the spreading of cooperation from one area to another". A more detailed definition is given by Stone Sweet (2012), in which he defines them as being the production of "new cycles of feedback" (Stone Sweet, 2012, p. 8). Stone Sweet continues, "In its most basic form, spillover occurs when actors realize that the objectives of initial supranational policies cannot be achieved without extending supranational policy-making to additional, functionally related domains" (ibid.).

A further definition of spillover is given as,

a situation in which a given action, related to a specific goal, creates a situation in which the original goal can be assured only by taking further actions, which in turn create a further condition and a need for more action. (Lindberg, 1963, p. 10 , cited in Wunderlich, 2007, p. 14)

The notion of spillover is further divided in to two parts: political spillover and functional spillover. The political spillover concept focuses on the role of supranational institutions, as well as subnational actors, "as they create further pressure for more integration to pursue their interests" (Sonny, 2015, p. 1). Wunderlich (2007, p. 15) furthers the idea of political spillovers requiring a form of supranational institution, "careful direction and coordination by a central agency is required for spillover to occur. ... the creation of a High Authority with supranational powers". Since political spillover is directly linked with the building of a political community and the "pooling" of sovereignty within a supranational institution, this paper will not concern itself in particular with this spillover effect. ${ }^{1}$

On the other hand, functional spillovers are more confined and focus on the expansion of cooperation in one specific policy area to related areas. Sonny $(2015$, p.1) defines functional spillover as, "the way on which integration in one policy area ... creates pressure for integration in further areas". Whilst this does arguably relate to regionalization, the narrower view can be taken as one policy area simply connecting and forming

\footnotetext{
${ }^{1}$ For further specific details on political spillovers see Ilievski, N. J. (2015), "The Concept of Political Integration: The Perspectives of Neofunctionalist Theory”, Journal of Liberty and International Affairs, 1(1), UDC 327|ISSN 1857-9760.
} 
linkages with other policy areas. As Mattli (1999, p. 23) points out, with regards to general functionalist theory, "it is ... a normative method. It describes a way that should be pursued to attain peaceful coexistence".

Whilst Mitrany and Haas viewed functionalism/neofunctionalism and its corresponding spillover effect through the lens of political community building through regional integration-namely global integration and the integration of Western European states, respectively - the concept of spillovers can be, and has been, applied to more specific cases of international relations and further still to defined policy areas in domestic politics. Truelove, Carrico, Weber, Raimi, and Vandenbergh (2014), for instance, wrote a comprehensive study on the positive and negative spillovers in environment policy, while Angelucci and Di Marro (2015) offer a practical insight about providing evaluations for spillover effects, noting numerous different applications in which spillovers can occur, including welfare programs, genetically-modified crops, and immunization programmes, amongst others.

\section{Ostpolitik}

This section begins to analyze the policy reversal of the Federal Republic of Germany (FRG) ${ }^{2}$ with regards to its relations with the German Democratic republic (GDR). In context, this is an important policy shift, since it set in motion a chain of events that started to develop spillover effects that led to economic, political, and social exchange, and facilitated the later reunification. More importantly, the advent of Willy Brandt's Ostpolitik began against the backdrop of the Cold War, a period when the entire European continent was nuclearised. This section will show that rather than focusing on the "high politics" of denuclearization, instead Brandt's concept of rapprochement was more successful and indeed leads to peaceful coexistence.

\section{Pre-Ostpolitik Relations}

The post-WWII situation in Germany was symbolic of the wider ideological divide that was washing over Europe and the wider world. After the events of $1948^{3}$, the inclusion of the "West German state" into the International Monetary Fund (IMF) in $1952^{4}$ and the later implementation of the Hallstein Doctrine in 1955, the division between East and West Germany was solidified. Of these events, the Hallstein Doctrine was arguably the most important, since under the Doctrine "the Federal Republic would reduce or sever diplomatic ties with any government (apart from the Soviet Union) which recognized the GDR as a sovereign state" (Riordan, 1995, p. 676). The doctrine, introduced by the then Chancellor of the West German state, Konrad Adenauer, effectively set an aggressive foreign policy approach to relations with the communist bloc, whilst at the same time, strengthening the alliance between West Germany and the emerging European community ${ }^{5}$. In 1954, the FRG had also been accepted as a member of NATO, leading to the establishment of the Warsaw Pact in 1955 as a communist-version of the western security organization.

\footnotetext{
2 The Federal Republic of Germany (in German, Bundesrepublik Deutschland, BRD) was the official name of the West German state. Its opposite half was the German Democratic Republic (in German Deutsche Demokratische Republik, DDR).

${ }^{3}$ In 1948 the London Conference increased calls for a united Western German state comprising of the three zones under administration by the US, France, and the UK, after the USSR had rejected any offers of Marshall Aid being provided to the eastern zone. The resulting "conflict" saw all land-based transportation links cut-off to the Western sectors in Berlin between June 1948 and May 1949. This incident can be considered as the symbolic start of the Cold War.

4 This was possible since the three administrating powers had granted the West Germans limited sovereignty.

${ }^{5}$ In 1952 the European Coal and Steel Community had come in to force and following the failure of the European Defense Community (EDC) in 1954, the Messina Conference in 1955 began the negotiations for what, two years later, emerged as the Treaty of Rome.
} 
Konrad Adenauer, having been elected as the first Chancellor of the FRG in 1949, stayed in power until 1963, after which he was succeeded by fellow Christian Democrat and long-term economic minister Ludwig Erhard. ${ }^{6}$ Erhard remained in office until 1967, although he oversaw a period in which the Grand Coalition of the CDU-SPD became weak, leading eventually to the Social Democratic party winning power in 1969 under a new coalition with the liberals. Willy Brandt, as leader of the SPD, became Chancellor in 1969. As Noetzoldt (1998, p. 22) mentions, this had some major implications,

The new government made it apparent that it would embark on a new conciliatory course toward Eastern Europe and the USSR that it wished to conduct an active foreign policy, more independent from the United States and other major allies and that, unlike the conservative CDU/CSU, it was ready to compromise with the Soviet-led orbit in Eastern Europe. In his first government declaration on October 28, 1969, Chancellor Brandt proposed a new policy of detente toward Eastern Europe and the Soviet Union.

When it came down to it, "Brandt was more interested in long term objectives than in short term results" (Handrieder, 1981, cited in Noetzoldt, 1998, p. 4). The reasoning behind Brandt's decision to apply a policy of détente was the failure of the Hallstein doctrine to force any change in the division of Germany, as Fink and Schaefer $(2009$, p. 2) note,

Brandt and his close adviser Egon Bahr recognized that the "German problem" would not be solved by the superpowers, who seemed content with the "two-state solution". Brandt and Bahr ... jointly and gradually devised a new approach to the Cold War with West Germany as an active player pursuing its own interests.

This has strong similarities with the Korean division, where the superpowers of the US and China have played a significant role to the detriment of Korean sovereignty.

Prior to the election of Brandt, relations between both Bonn and East Berlin and Bonn and Moscow were poor to say the least. Stent (2002, p. 177) summarizes the main difference that Ostpolitik introduced, "Brandt's Ostpolitik represented a more fundamental alteration of German foreign policy goals than Brezhnev's Westpolitik $^{7}$ of Soviet foreign policy goals. The FRG had ceased to be a revisionist power politically". In simple terms, Brandt no longer pursued a policy that aimed for change, but instead pursued a policy of coexistence and accepting the reality of a divided Germany. Fink and Schaefer (2009, pp. 3, 4) continue the idea that Brandt was following a polar-opposite foreign policy, stating,

His $\{$ Brandt $\}$ frank confrontation with the German past-combined with Bonn's eagerness to de-emphasize Cold War polarities - enabled the chancellor and his colleagues to pursue German political and economic interests even more assertively than his Christian Democratic Union (CDU) predecessors.

Brandt's Ostpolitik truly saw big changes in West German policy. Noetzoldt (1998, p. 26) notes, "One of the first major steps of the social-liberal coalition toward detente occurred on November 28, 1969 with the Federal Republic's signing of the non-proliferation treaty (N. P. T.)". Whilst this will be discussed in more detail in the next sub-section, it also points towards another similarity between the current divide on the Korean peninsula, with South Korea having also signed the NPT and committed to being nuclear weapons-free.

\footnotetext{
${ }^{6}$ Adenauer resigned his position as Chancellor having achieved his goal of signing a cooperation agreement with France, although he remained the Chairman of the Christian Democratic Union (CDU) until 1966.

7 The basic foundation of the Westpolitik was to ensure that the FRG did not attempt to re-define the Eastern border of Germany and to leave them as they existed at the end of WWII. Stent (2002, p. 177) notes, "The goal of Soviet Westpolitik, which the Kremlin had consistently pursued since 1955 , had been achieved".
} 


\section{Features of Ostpolitik}

The implementation of Brandt's Ostpolitik was well accepted by both domestically and internationally, yet it was also met with heavy criticism. Niedhart (2003, p. 120) states that "The CDU/CSU opposition complained that Ostpolitik was a capitulation to Moscow and the final acceptance of the division of Germany". The major capitulation was a reference to the policy that recognized the territorial borders as they were at the end of WWII, specifically the Oder-Neisse line. Stent (1990, p. 6) also notes that "Basket One of the final act of 1975 recognized the current borders of Europe". 8

The final acceptance referred to the end of the Hallstein doctrine. Through the new Ostpolitik the FRG was now willing to have diplomatic relations with any state that recognized the GDR, in effect the FRG now recognized the GDR as an independent state. As such, Brandt and his close advisors were quick to capitalize on the rapidly thawing relations and within a couple of years several agreements had been signed, most notably; the Moscow Agreement, signed on 12 August, 1970, a treaty with Poland in December, 1970, the Allied Agreement on 3 September, 1971, and the Basic Treaty was signed on 21 December, 1972, formally recognizing each state and normalizing diplomatic and trade relations. In addition, the more problematic treaty regarding relations with Czechoslovakia was also brought to the negotiating table, with the thorny issue of how to resolve the Munich Agreement of 1938 and German citizens having been deported at the end of the war from the Sudetenland. ${ }^{9}$ What this brief rundown of events shows is that if a serious push towards establishing basic relations is approached first, then more complicated issues can be resolved later, once a degree of trust and interdependence - positive spillovers - has been built.

In fact, the relative urgency of the Bonn administration to complete agreements also took it away from the position of its close Western allies, namely the US. Despite that, Brandt was keen to push on and enforce the reforms he intended to, but at the same time keep the allies informed. Niedhart (2003, p. 125) states, "Bonn's policy of linkages ran parallel but not always in complete harmony with Kissinger's efforts to construct linkages", the linkages referring to Bonn's bilateral relations with its neighbouring states and the USSR. Similarities with the Korean case can again be made, with Seoul pushing for improved bilateral relations, maybe slightly out of line with the wishes of Washington. Is Seoul mirroring the Brandt administration's stance of regaining some of its lost "liberty"? Niedhart (2003, p. 123) quotes the British ambassador to Bonn at the time as saying, "Among its features are a greater self-reliance, a feeling that the period of atonement for the war is over, impatience with restraints on German liberty of action". This is significant because, as the next section will discuss, the North Korean policy coming out of the US over the past two decades has been one of hard power driven, unilateral denuclearization of the DPRK. The current Moon administration, on the other hand, was elected into office on the campaign manifesto of engagement with the North and improving relations in a (somewhat) return to the Sunshine Policy of Kim Daejung.

Brandt's Ostpolitik, as Quigley states, was not completely new ${ }^{10}$, but instead it was the re-framing of former German reunification policies that had failed, but that still encompassed the basic characteristics of "establishing trade relations, expanding human contacts, and placing priority on relations with Moscow" (1994,

\footnotetext{
${ }^{8}$ Crump (2014) gives a detailed analysis of the domestic (within the USSR) divisions that existed with regards to the Westpolitik. See pp. 153-198.

9 For more detailed information on the individual agreements see Haftendorn, H. (2006), "Ostpolitik and Détente: Rapprochement With the East”, in Haftendorn, H. (2006), Coming of Age: German Foreign Policy Since 1945 (ch. 5, pp. 157-195). Lanhma, Md: Rowman \& Littlefield.

${ }^{10}$ Hence Brandt's Ostpolitik is generally referred to as "Neue Ostpolitik", New Eastern policy.
} 
p. 41). There are stark similarities with the South Korea engagement policy introduced by Kim Daejung, but also more recently by incumbent President Moon Jae-in. Moreover, the policy includes no pre-conditions for successful negotiations, whereas the current US policy towards North Korea hinges firmly on denuclearization.

\section{Ostpolitik and Non-proliferation}

Maintaining the basic tenet of this paper, the nuclear problem did exist during the entire Cold War period, and as such when Brandt was reforming the FRG's foreign policy, yet from the start the notion of denuclearization was not a deal-breaker. In other words, it was a part of the problem, but not the main problem. Indeed, Brandt's basic aim was to garner basic relations first through political relations and also by ending the use of economic disincentives (Stent, 2002, pp. 177, 178).

Under Brezhnev the nuclear arms race did become a concern for the Western alliance, and the FRG. Crump (2014, p. 155) remarked that "Détente could, according to Brezhnev, only be cultivated from a position of strength, and between 1965 and 1970 the Soviet expenditure on defense increased by 40 percent in order to reach nuclear parity with the United States". Crump noted further that this policy of military spending was a reversal of Khrushchev's policy of reducing spending on conventional forces (2014, p. 156).

Militarism and the nuclear sandwich that the FRG found itself trapped in was a major area of concern. Allin (2015), in an article about Egon Bahr's role in Ostpolitik, writes, "He likewise confirmed that he made no secret, in his conversations with Kissinger, that Ostpolitik was driven by nuclear necessity", although this "nuclear necessity" was the driver not of talks for rapprochement through denuclearization, but instead ensuring the FRG's security through détente. Likewise, in the current Korean situation, for the two Koreas, détente should be the first step in a much longer process, with the long-term goals of denuclearization.

It is necessary to mention that the 1960 s had seen a general trend to somewhat limit the militarization of Europe and stop the spread of nuclear weapons. Haftendorn summarizes,

The Test Ban Treaty was followed by the Treaty on the Non-Proliferation of Nuclear Weapons (NPT) in 1968. In addition, in the late sixties the Soviets and Americans began negotiations on strategic arms limitation (SALT) as well as on foregoing the construction of antiballistic missile systems (ABM). (2006, p. 157)

This important background provides an opportunity for Brandt to avoid any encroachment on to military issues that may otherwise have proven too difficult to overcome.

Haftendorn furthers the argument that negotiation should be based around trust-building measures and policies that can further spillovers and cooperation by noting that the FRG was encouraged, in 1966, by politicians from both the US and USSR "to give up its entrenched position and work toward improvement in East-West relations and stop making it conditional on progress on the German question" (2006, p. 158). The ongoing, and still firm, position of the US towards any deal with the DPRK is fully conditional on the DPRK's willingness to denuclearize along the lines of CVID. The next section will focus on the lack of spillovers that can be created through this tactic.

\section{Korean Peninsula}

The Korean peninsula has, for several decades, been the continuing legacy of the Cold War. It has maintained the ideological divide between the two opposing political systems, and has often resorted to threats and isolated acts of aggression. The main issue, however, has centered on the ceaseless development of nuclear weapons by the DPRK's leadership, despite international condemnation. Based on this weapons program, from 
the early 1990s right through to the present day, there has been a rollercoaster of relations among the DPRK, Republic of Korea, and their allies - namely China and the US. Yet the reason behind these inconsistent relations has been the unwavering policy of the US to demand complete denuclearization of the DPRK as a pre-condition to further negotiations. This policy must be reformed to follow Brandt's Ostpolitik of détente leading to an atmosphere conducive to denuclearization.

\section{CVID}

Since the Bush administration (2001-2008) the US has followed the policy of Complete, Verifiable, Irreversible, Dismantlement (CVID) of the North Korean nuclear weapons program and related facilities. In his June 2018 statement, Victor Cha, in a testimony to the Senate Committee on Foreign Relations, stated, "The United States must maintain that the objective of our negotiations is the complete end to North Korea's WMD and missile threat". Based on a report from CNN journalist Joshua Berlinger, the day before the US-North Korea summit on June 12, US Secretary of State Mike Pompeo was quoted as saying, "Sanctions will remain until North Korea completely and verifiably eliminates its mass-destruction programs", confirming that the US position on denuclearization has not changed.

The CVID policy itself is not necessarily a bad one, after all it aims at denuclearizing the Korean peninsula and thus establishing sustainable peace in the region. In the 1994 Agreed Framework ${ }^{11}$, the DPRK agreed to give up its nuclear weapons program in exchange for aid in various forms, and thus the current situation will be loosely based on the agreement previously accepted. However, that agreement ended up failing and subsequently the DPRK withdrew from the Treaty on the Non-proliferation of Nuclear Weapons in 2003 and officially restarted its nuclear weapons program. ${ }^{12}$

What are the implications of past events regarding the DPRK and its actions regarding nuclear agreements? Simply, they show that the DPRK is not to be fully trusted, on the one hand, whilst on the other, it shows that once the agreements based centrally on the ending of nuclear weapons programs was violated then all relations were cut off. Following the theory of spillovers, nuclear-oriented agreements with the DPRK create no spillovers. Greenstein and Polsby (1975, p. 384) remarked, "Not only may spillover in some cases not occur at all; in others, the response can be negative. Dissatisfied actors may decide to undo the original linkage, rather than become enmeshed more thoroughly in the process". In the 1994 Agreed framework the DPRK simply got to a point where it wanted to break the linkage. Since no trade or economic ties were formed, i.e., interdependence had not been established, this linkage break was clean and swift.

On June 12, 2018, President Trump and Chairman Kim met in Singapore. They signed a document declaring their intentions, which again had denuclearization efforts at the heart of it. ${ }^{13}$ Whilst the document is

\footnotetext{
11 For specific details of the terms of the 1994 Agreed Framework, see Kim, S. S. (2006), The Two Koreas and the Great Powers. New York: Cambridge University Press. Ch. 5. In particular, p. 252.

${ }^{12}$ It is generally accepted that the Agreed Framework was being implemented, although the DPRK had secretly been continuing with its nuclear weapons program until it was discovered in the late 1990s. Victor Cha (2013, p. 247) points out, "There were concerns about DPRK nuclear cheating at a suspected underground facility at Kumchangri in 1999”. Samuel Kim, on the other hand, says that the North Koreans never actually stopped their weapons program, "A majority of Russian experts believe that Pyongyang never completely halted work on its military nuclear program, despite signing the Agreed Framework in 1994" (2006, p. 131).

13 The exact details of the document signed are: "The United States and the DPRK commit to establish new U.S.-DPRK relations in accordance with the desire of the peoples of the two countries for peace and prosperity; The United States and the DPRK will join their efforts to build a lasting and stable peace regime on the Korean Peninsula; Reaffirming the April 27, 2018 Panmunjom Declaration, the DPRK commits to work toward complete denuclearization of the Korean Peninsula; The United States and the DPRK commit to recovering POW/MIA remains, including the immediate repatriation of those already identified" (Rosenfeld, E., "Read the Full Text of the Trump-Kim Agreement Here", CNBC. June 12, 2018. https://www.cnbc.com/2018/06/12/full-text-of-the-trump-kim-summit-agreement.html (accessed June 12, 2018).
} 
merely a statement of intention and not a specific agreement, it clearly shows a lack of economic and trade linkages, but focuses more on general relations and denuclearization. The current situation can learn from the engagement processes of Ostpolitik and Kim Daejung's Sunshine Policy by encouraging increased trade and exchanges, whilst simultaneously applying gradual pressure towards denuclearization. As Fink and Schaefer (2009, p. 2) noted, Brandt, amongst other important issues, "renounced the use of force and the acquisition of nuclear weapons". As such, the issue became a smaller part of a much bigger framework agreement.

\section{Engagement}

Since the Basic agreement of 1991 relations between the North and South have somewhat improved - at times. There have been periods of engagement, and periods of heightened tension. ${ }^{14}$ During Roh Tae-woo's term in office (1988-1993) a new engagement policy, Nordpolitik, ${ }^{15}$ was introduced which "sought diplomatic normalization with communist bloc countries and then attempted to pursue engagement with North Korea" (Lee \& Moon, 2016, p. 226). The basic Agreement had followed earlier declarations from President Roh that South Korea wanted to restart and develop inter-Korean trade, in a move way from confrontational relations. Significantly, "the RTW administration adopted the principle of separation of economics and politics, significantly fostering inter-Korean economic relations" (2016, p. 227). The Nordpolitik was continued on through the Kim Young-sam administration (1993-1998), at the start of which the leaders of South and North Korea agreed to meet in the first inter-Korean summit. ${ }^{16}$ As mentioned, above, despite the failure to realize the inter-Korean summit, the 1994 Agreed Framework was signed. A clear spillover effect can be seen from the engagement process of Nordpolitik between 1988 and 1994, although the Framework Agreement produced no spillovers, thus ending all progress, or even going as far as to produce "negative spillover ('spillback')" (Wunderlich, 2007, p. 22).

The high point of relations came with the term in office of President Kim Daejung. The liberal leader, after a few years of instability following the inauguration of Kim Jong-il as Chairman and the complications of enacting the Agreed framework through Korean Peninsula Development Organization (KEDO) ${ }^{17}$, took office in 1998 and declared, as one of his six major initiatives for reform in South Korea, "I intend to promote a new relationship of exchanges and cooperation between the South and the North", after which he continued, the government "will remove the wall of distrust between the two Koreas to promote exchanges and cooperation in accordance with the principles of separating politics and economics" (Kim Daejung, 1998 Address, Korea Observer, Autumn 1998).

The policy of trust and confidence building follows the new Ostpolitik of Brandt. Quigley (1994, p. 43) states, "By relaxing tensions and building trust and confidence between East and West, the West would encourage the rulers in the East to relax their iron grips at home". For Kim Daejung the same would happen in North Korea through cooperation. The Sunshine Policy that Kim implemented had, according to Moon (2012),

\footnotetext{
${ }^{14}$ In particular, in 2010 the North attacked South Korea in two separate incidents, one sinking a South Korean navy corvette and on the other occasion the island of Yeonpyeong was shelled by North Korean artillery.

${ }^{15}$ Under the Nordpolitik, South Korea "normalized diplomatic ties with communist countries, first with Hungary in 1989, then Poland and Yugoslavia in 1989, the Czechoslovakia, Bulgaria, Mongolia, Romania, and the Soviet union in 1990, and finally China in 1992" (Lee \& Moon, 2016, p. 226).

16 That summit did not happen due to the sudden death of North Korean leader Kim Il-sung in July 1994.

17 The Korean Peninsula Development Organization (KEDO) was set up to finance and organize the actualization of the two light-water reactors promised to North Korea in the 1994 Agreed framework.
} 
had five "major ideals"18 and five "operating principles"19, of which amongst the five operating procedures the second principle of "flexible dualism" referred to "the sequence of inter-Korean engagement" (2012, p. 26). The specific sequence was listed as follows, "(1) Easy tasks first, difficult tasks later, (2) Economy first, politics later, (3) Non-governmental organizations first, government later, (4) Give first, take later" (ibid.). As Lee and Moon (2016, p. 228) state in their analysis of "flexible dualism", "previous governments were preoccupied with the primacy of politics and its linkage to the economy, which entailed structural barriers to the promotion of inter-Korean exchanges and cooperation". Thus the Sunshine Policy's approach was a reversal of this old approach, namely an economic engagement approach that would create linkages.

However, its final step of the sequence - "give first, take later"-became a thorny issue both within domestic South Korean politics and also within the general public. Moon (2012, p. 34) points out that "The Sunshine Policy encountered no major domestic setback or opposition at the start. The public generally supported it", whilst Kirk (2001, p. 410) also notes that in December 2000, “among 26,300 respondents ... 66 percent were in favor" of Kim Daejung receiving the Nobel Peace prize. However, the optimism and praise for the policy was wearing off at this point. Kirk then goes on to say, "Respondents were far less enthusiastic about the government's efforts to implement the Sunshine Policy by providing assistance to North Korea without compensation in return" (ibid.).

This point should be noted for any future engagement policies towards the North. The existing infrastructural development in Kaesong - the industrial park - and the Mount Kumgang tourist complex were both aspects of the Sunshine Policy and they created an economic linkage, and to a degree social linkage, between the two Koreas. However, they have both been closed down due to the poor relations - the Mount Kumgang complex in 2008 following a shooting incident which resulted in the death of a South Korean woman, and the Kaesong industrial complex in 2016 following rising tensions over the DPRK's nuclear and missile testing programs.

\section{Framework for Success in Korea}

This section will provide a possible framework for a successful new agreement, based on the German and Korean experiences with Ostpolitik and Sunshine Policy.

Without doubt, the framework will follow the Ostpolitik and assume that there are no pre-conditions, in this case that means that the issue of denuclearization should not be an initial condition. That is not to say it should be excluded altogether, but it remains a longer term goal that can be achieved following the success of the earlier cooperative processes. As mentioned earlier, Brandt recognized that the Hallstein Doctrine and related policies of confrontation had made no progress in improving relations between the FRG and GDR. Similarly, the nuclear problem in Korea has been the major stumbling block towards developing relations in northeast Asia.

Continuing on, the framework should start from a point of furthering trade and economic ties, but through a continuation and expansion of the industrial and tourist zones in North Korea, helped financially by the South and its allies. In an op-ed piece for Brookings, Lee (2015) wrote that "Advocates say tourism facilitates much-needed cross-cultural learning, with foreigners experiencing that North Koreans are as human as anyone else, and North Koreans getting information about life outside their borders through their visitors from abroad".

\footnotetext{
18 See pp. 21-25.

19 See pp. 26-30.
} 
Tourism could therefore act as both an economic incentive, as well as a social learning process. This furthers spillover in that as the North Koreans become more exposed to foreign cultures and products they will demand further opening up, creating increased interdependence.

The process of developing economic links through trade and industry will take time. The new framework must therefore be willing to take small steps, rather than big steps, but recognize that these smaller steps will eventually lead to the establishment of trust, cooperation, and economic growth and interdependency. Once such links are created then the second major phase, political and security measures can be negotiated. The key point is, that strong linkages that are very difficult and costly to break, must be created first through engagement, before tougher issues are brought to the table.

Thus the framework should go as follows:

1. Sign a basic agreement that promises a new atmosphere of engagement and peaceful cooperation, with long term goals of peace, security, and prosperity

2. Begin by implementing economic policies that create strong links between the two Koreas, and North Korea and other countries. This could involve reopening Kaesong and Mount Kumgang.

3. Introduce more exchanges both economically, infrastructurally, and socially. Encourage tourism in certain areas of the DPRK, allowing for economic growth and social spillover. Provide training and education for infrastructural improvements in the North. This would include cooperation with outside construction companies, for example.

4. With progress, introduce more political and security issues into discussion, for example human rights issues and political prisoners. Having established economic growth and dependence, these trickier issues will be less difficult to negotiate.

5. Approach reductions and limitations of armaments, with a timeline for disarmament on certain categories.

\section{Conclusion}

The current situation on the Korean peninsula is finely balanced. It could be the start of a new era of peaceful and prosperous relations between the two Koreas and their allies or it could be the continuation of a pattern of good and bad relations. What is clear is that there is an opportunity and with the right approach the former is highly possible. It all depends on the specific type of any agreement that is negotiated.

As we have seen with Willy Brandt's Neue Ostpolitik in the late 1960s/early 1970s a dramatic reversal in policy can create positive relations and spillovers, resulting ultimately in peaceful co-existence and prosperity for all. Moreover, the German example shows that even under the gloomy cloud of nuclear deterrence and heavy militarization, peace can be achieved through a functional process, developing economic and social linkages, rather than coming to agreements by demanding the resolution of pre-conditions. Whilst the major problem was different in the German and Korean cases, Brandt's decision to forego the "German question", in particular territorial claims, proved pivotal in forging cooperation and trust between the two Germanies.

In Korea, the advent of democracy has also seen, since the late 1980s, a shift in policy towards North Korea. Starting with basic non-aggression treaties and moves to develop a stronger, more cooperative relationship was working, until the 1994 Agreed framework focused too much on political and security linkages, resulting in the failure of all negotiations. The lack of spillovers that comes with political deals cannot work in future agreements with the DPRK. There must be a return to the Sunshine Policy of Kim Daejung that focused 
on building economic ties and gradually building trust and interdependence, followed later by more difficult issues such as political issues and denuclearization.

Yet the Sunshine Policy itself cannot simply be reinstated. As seen, whilst its basic theory was sound, the idea of "give first, take later"' was a crux in the whole deal. The South Korean public began to disapprove of the government's generosity towards the North while receiving very little in return. As such, any new policy should focus on helping the North build its economy and developing strong inter-Korean trade links, as well as trade links between the DPRK and other countries. In doing so, this will strengthen the DPRK's economy and at the same time induce an environment of security wherein nuclear weapons will be seen as unviable and unnecessary.

\section{References}

Allin, D. H. (20 August 2015). Egon Bahr and the legacy of Ostpolitik. IISS. Retrieved from https://www.iiss.org/en/politics\%20and\%20strategy/blogsections/2015-932e/august-c020/egon-bahr-and-the-legacy-of-ostpo litik-dcc9 (accessed June 12, 2018)

Angelucci, M., \& Di Marro, V. (2015). Program evaluation and spillover effects. Institute for the Division of Labor (IZA), Discussion Paper No. 9033.

Berlinger, J. (June 11, 2018). Trump-Kim summit: North Korean leader to talk denuclearization. CNN. Retrieved from https://edition.cnn.com/2018/06/10/asia/north-korea-summit-denuclearization-talks/index.html (accessed June 12, 2018)

Börzel, T. A. (2013). Comparative regionalism: European integration and beyond. In W. Carlsnaes, T. Risse, and B. A. Simmons (Eds.), Handbook of international relations (pp. 503-530) (2nd ed.). Los Angeles, London, New Delhi, Singapore, Washington DC: SAGE.

Cha, V. (2006). The impossible state: North Korea past and future. London: Vintage Books.

Cha, V. (June 5, 2018). Next seps on U.S. policy toward North Korea (Statement before the Senate Committee on Foreign Relations Subcommittee on East Asia, the Pacific, and International Cybersecurity Policy). Center for Strategic and International Studies.

Chari, R. S., \& Kritzinger, S. (2006). Understanding EU policy making. London \& Ann Arbor: Pluto Press.

Crump, L. C. (2014). The Warsaw Pact reconsidered: Inquiries in to the Evolution of an Underestimated Alliance, 1960-1969. University of Utrecht.

Daddow, O. (2013). International relations theory: The essentials. Los Angeles, London, New Delhi, Singapore, Washington DC: SAGE.

Fink, C., \& Schaefer, B. (2009). Ostpolitik and the world, 1969-1974. In C. Fink and B. Schaefer (Eds.), Ostpolitik, 1969-1974: European and global responses (pp. 1-10). New York: Cambridge University Press.

Greenstein, F.I. \& Polsby, N.W. (1975). Handbook of Political Science. International Politics. Reading, Massachusetts: Addison-Wesley Pub. Co.

Haftendorn, H. (2006). Ostpolitik and détente: Rapprochement with the East. In H. Haftendorn, Coming of age: German foreign policy since 1945 (ch. 5 pp. 157-195). Lanham, Md: Rowman \& Littlefield.

Handrieder, W. (1981). Fragmente der Macht. Die AuBenpolitik der Bundesregierung. Milnchen: Piper.

Heywood, A. (2007). Politics (3rd ed.). Basingstoke \& New York: Palgrave Macmillan.

Kim, D.-J. (1998). Let us begin the second nation-building. Korea Observer, XXIX(3), 599-610.

Kim, S. (2006). The two Koreas and the great powers. New York: Cambridge University Press.

Kirk, D. (2001). Kim Dea-jung and sunshine: Polls, popularity and politics. Korea Observer, 32(3), 409-429.

Lee, J. H. (June 9, 2015). Tourism to North Korea: Unethical or an opportunity for engagement? Brookings. Retrieved from https://www.brookings.edu/opinions/tourism-to-north-korea-unethical-or-an-opportunity-for-engagement/ (accessed June 13, 2018)

Lee, S., \& Moon, C. (2016). South Korea's economic engagement toward North Korea. In Joint US-Korea academic studies (pp. 226-239).

Retrieved

from

http://www.keia.org/sites/default/files/publications/joint_us-korea_2016_-_sk_econ_engagment.pdf

Mattli, W. (1999). The logic of regional integration: Europe and beyond. Cambridge: Cambridge University Press. 
Moon, C. (2012). The Sunshine Policy: In defense of engagement as a path to peace in Korea. Seoul: Yonsei University Press. Niedhart, G. (2003). Ostpolitik: Phases, short-term objectives and grand design. GHI. Bulletin Supplement I.

Noetzoldt, L. J. (1998). How West Germany's Ostpolitik contributed to German Unification (Master's Thesis). Retrieved from http://thekeep.eiu.edu/theses/1741

Quigley, D. D. (1994). Ostpolitik and its relevance to Inter-Korean relations. In K. Oh and C. S. Coleman, Restarting the peace process on the Korean Peninsula (pp. 37-57). Conference hosted by RAND/Center for Asia-Pacific Policy. Retrieved from https://www.researchgate.net/profile/Denise_Quigley/publication/235906972_Ostpolitik_and_Its_Relevance_for_Inter-Kore an_Relations/links/557077a708ae193af42000ef/Ostpolitik-and-Its-Relevance-for-Inter-Korean-Relations.pdf (accessed June $11,2018)$

Riordan, C. (1995). From Hallstein to Sinatra: Cultural reflections of political relations between the two Germanies, 1965-85. The Modern Language Review, 90(3), 676-687.

Sonny, A. (2015). Theories of European integration. CIVITAS. Institute for the Study of Civil Society.

Stent, A. E. (1990). The Soviet Union, Eastern and Western Europe before and after German Unification. National Council for Soviet and East European Research. Retrieved from https://www.ucis.pitt.edu/nceeer/1990-800-02-Stent.pdf

Stent, A. E. (2002). From Embargo to Ostpolitik: The political economy of West German-Soviet relations, 1955-1980. London, New York, Melbourne, New Rochelle \& Sydney: Cambridge University Press.

Stone Sweet, A. (2012). Neofunctionalism and supranational governance (unabridged version). Faculty Scholarship Series. Paper 4628.

Truelove, H. B., Carrico, A. R., Weber, E. U., Raimi, K. T., \& Vandenbergh, M. P. (2014). Positive and negative spillover of pre-environmental behavior: An integrative review and theoretical framework. Global Environmental Change, 29, $127-138$.

Wunderlich, J.-U. (2007). Regionalism, globalization and international order: Europe and Southeast Asia. Hampshire \& Burlington: Ashgate Publishing Company. 